\title{
Lady Rosaline's Darkness: Linguistic Games and Deep Meanings
}

\section{Camilla Caporicci}

\section{Q OpenEdition \\ 1 Journals}

\section{Electronic version}

URL: http://journals.openedition.org/shakespeare/2911

DOI: 10.4000/shakespeare.2911

ISSN: 2271-6424

\section{Publisher}

Société Française Shakespeare

\section{Electronic reference}

Camilla Caporicci, «Lady Rosaline's Darkness: Linguistic Games and Deep Meanings », Actes des congrès de la Société française Shakespeare [Online], 32 | 2015, Online since 10 March 2015, connection on 24 July 2020. URL : http://journals.openedition.org/shakespeare/2911; DOI : https://doi.org/ 10.4000/shakespeare.2911

This text was automatically generated on 24 July 2020 .

(c) SFS 


\title{
Lady Rosaline's Darkness: Linguistic Games and Deep Meanings
}

\author{
Camilla Caporicci
}

1 Behind its lively love stories, Love's Labour's Lost conceals an extremely dense and controversial subtext. Rather than attempt a topical reading of the play - a not uncommon approach to the analysis of this difficult text ${ }^{1}$-, this paper aims to show the aesthetic and philosophical complexity of Shakespeare's discourse, one that conveys, through a particularly sophisticated and sometimes paradoxical language, deeply innovative meanings.

2 By focusing the attention on the play's main processes, it is possible to notice two strictly related passages, both of which find their main symbol in the darkness of Lady Rosaline. From an aesthetic and poetic standpoint, Shakespeare makes Rosaline's darkness the rock on which the traditional Petrarchan lyric founders. Through a subtle, effervescently ironic discourse, the falsifying character of the Petrarchan rhetorical language is revealed, while the Neo-platonic ideal at the basis of the sonnet tradition, chromatically characterized as luminous and white, crashes against the obscure materiality of the lady's body. Concurrently, the exceptionally complex linguistic game through which Shakespeare ambiguously intertwines light and darkness throughout the text expresses the play's ontological and epistemological discovery, one that is embedded in the new sensibility rising in Europe at the end of the sixteenth century.

\section{"The mind shall banquet, though the body pine": The Dichotomous Worldview}

Love's Labour's Lost opens with the King of Navarre proclaiming his plan to acquire semidivine knowledge and status through the renunciation of bodily pleasures and vile earthly passions. Through this war against human affections and "the huge army of the world's desires," the king hopes to annihilate the distracting and degrading influence of the flesh; in quite paradigmatic words, he exclaims, "The mind shall banquet, though the body pine" (I.i.25). By opening the play with such a clear programmatic statement, 
Shakespeare evidently aims to immediately link the king's initial worldview with the ontological and epistemological paradigm dominant in the Renaissance: a paradigm essentially based on the principle of hierarchical dichotomy. The dualistic opposition of spiritual and material planes informed every aspect of Renaissance thought, from the ontological and epistemological reflection to the concept of man and of art. In this context, the perpetual struggle between soul and body represents the axiom upon which the concept of man was built, affirming the unmistakable superiority of the spiritual and thinking entity over the material and physical one. This dichotomous worldview found its basis in both the theological and the philosophical paradigm of the period, grounded on a deeply Christianized combination of Stoicism and NeoPlatonism. While the Protestant anthropological pessimism ${ }^{3}$ and the Stoic ideal do not appear to play a crucial role in the king's vision, Neo-Platonism seems more influential. Neo-Platonism, in the Christianized form elaborated by Ficino's Florentine Academia, is much more optimistic than Puritanism and Stoicism about man's possibilities of perfection, and considers the human being a wonderful creature, a "great miracle," 4 but only insofar as he chooses to transcend his most corporeal self and become an angelic mind by following the light of his pure intellect. Reaffirming a conflict that can be traced back to Plato's Phaedrus, the Neo-Platonic body does not play a significant role in the realization of the most authentic nature of man because, as Giovanni Betussi affirms, "l'anima è l'uomo, ed in quella consiste la vera bellezza. Ed il corpo è la sua prigione ed il suo sepolcro." ${ }^{5}$ As Ficino writes, the soul needs to detach itself from the body and adhere to the divine; only in so doing will it truly become copula mundi. ${ }^{6}$

4 This dichotomous and vertically oriented worldview, particularly in its Neo-Platonic interpretation, is undoubtedly the foundation of the king of Navarre's initial project. Through very meaningful terms, the king envisions the creation of a "little academe" (I.i.13), the "wonder of the world" (I.i.12). Its members shall be "mortified" (I.i.28), dead in their bodies and to the world's gross pleasures, and "living in philosophy" (I.i.32). In order to acquire true knowledge - which is significantly defined as an "angel" (I.i.113) the mind needs to detach itself from the vile body and its desires, especially in their sensual connotation. Upon the arrival of the dames of France, however, this plan is soon revealed to be fallacious. The passion that the women inspire in the young men obliges them to admit that they are made of "flesh and blood" (IV.iii.213), and therefore unable to annihilate their sensual desires, thus revealing the inconsistency of man's ideal as free from his bodily aspects.

\section{Lady Rosaline's Darkness}

Connected to the play's ontological discovery, Shakespeare calls into question the artistic and linguistic problem inherent in the language the men use to give voice to their newly kindled passion: the language of Petrarchan poetry. Petrarchan poetry, the Renaissance's most prominent poetic genre, is based on the same Christian and NeoPlatonic worldview that informs the ontological and epistemological paradigm of the period: on both a philosophical and artistic level, it presents a marked tendency towards the "ideal". The eulogistic and precious language through which this poetry celebrates the beloved aims to create a poetic object that, in leaving behind all the darkness of the material world, deviates from the natural being to embody the purity of the Neo-Platonic ideal. The falsification implicit in such a representation of reality is 
often the subject of Shakespeare's reflection. In many of his plays, and especially in his sonnets, Shakespeare meditates about the ethical problem posed by the language through which the celebrative praise is conveyed. Of particular interest to him was the implicit act of dishonesty that this language performs in the moment in which it gives birth to idealized figures, abstracted from the real objects they pretend to represent. In Love's Labour's Lost the main instrument of this criticism is irony. All the noble youths express their love through Petrarchan language, sometimes even in actual sonnets. However, the ladies to whom this language is directed do not appreciate a rhetoric that does not reflect their true nature. During her first appearance on the stage, the princess criticises the falsification inherent in the eulogistic Petrarchan praise: "my beauty, though but mean, / Needs not the painted flourish of your praise" (II.i.13-14). She also derides the mercenary character of this praise by playing on the chromatic opposition of fair and foul, thus reinforcing, as we shall see, the play's main symbolic discourse. To the Forester who calls her "fair", she first asks that he not "paint" her, affirming that she will give "fair payment for foul words" (IV.i.19). Next, she laughs at the praise that the Forester directs to her after taking the money, by acknowledging the hypocrisy implicit in a language that calls fair what is, in fact, foul in order to please the addressee: "O heresy in fair, fit for these days - / A giving hand, though foul, shall have fair praise" (IV.i.22-23). Recognizing the conventionality of the love verses, the French ladies define these verses as "A huge translation of hypocrisy" (V.ii.51). They perceive that this language, which is based on "Taffeta phrases, silken terms precise, / Three-piled hyperboles" (V.ii.406-407), celebrates an archetype that has nothing to do with their individual persons. For this reason, they refuse to accept the young men's courtship with an otherwise unaccountable obstinacy.

6 Not all the ladies, however, are equally falsified by the Petrarchan rhetoric. The one who is more severely betrayed by this eulogistic language is dark Rosaline. By presenting a lady on stage whose main characteristic is darkness, and by making of this darkness the center of the comedy's chromatic discourse, Shakespeare aims to give visual and symbolic representation to the play's main issues. Both the ontological and epistemological problem that Shakespeare addresses from the very beginning, along with his discussion of the Petrarchan model, are presented from a chromatic standpoint, in terms of a contrast between light and darkness. ${ }^{7}$ This approach finds its raison d'etre in the Renaissance chromatic universe. To the paradigm based on the hierarchically structured opposition of spiritual and material planes - which constitutes the foundation of the king's worldview and the Petrarchan ideal alike corresponded a universe equally contrasted with colour, based on the antagonism of white and black and the Neo-Platonic ladder of light. Originally grounded on the colour symbolism of Christian theology, according to which "white and black formed a pair of opposites and often represented the coloured expression of Good and Evil," code associating light with the divine realm and black with the postlapsarian world of matter and flesh, acquired even more importance during the Renaissance. ${ }^{9}$ In this period, the moral and mystical values attributed to white and black, and to light and darkness, were strengthened by the rebirth of Platonism in the form elaborated by Ficino. According to this doctrine, light is the perfect expression of the Good and "vinculum universi." 10

7 For this reason, the Neo-Platonic ideal celebrated by the Petrarchan language is rigidly codified in terms of colour. Beauty, God's manifestation that radiates into the world, is 
considered a ray of incorporeal light that must remain separated from the darkness of matter, because it loses much of its dignity when joined with it. ${ }^{11}$ Furthermore, in accordance with the Neo-Platonic definition of Amore Celeste and Amore Volgare, light and the colour white become the symbol of chaste and incorporeal love, while bestial, earthly lust is painted black, the dense and heavy colour of the sinful flesh. Consequently, the ideal lady must be as pure as snow, with shining hair, beaming sunlike eyes, and with a luminous soul that, in Castiglione's words, "col suo lume vince le tenebre del corpo."12 The idealization of the lady and the sublimation of her physical aspect is obtained through a sort of "whitening", a process through which the heavily dark body is purified and made insubstantial by endowing it with a translucent, light nature.

8 Given the importance of this chromatic characterization of the lady, Shakespeare's repeated insistence on Rosaline's darkness reveals his intention of challenging both the aesthetic and philosophical basis of Petrarchan and Neo-Platonic paradigms through the lady's colour. Rosaline, one of the main antecedents of the Sonnets' Dark Lady, ${ }^{13}$ is a negation of the traditional stereotype. She is a woman not at all fair and chaste; instead, she is dark and full of passion, "With two pitch-balls stuck in her face for eyes / Ay, and, by heaven, one that will do the deed / Though Argus were her eunuch and her guard" (III.i.192-194). The darkness of the body's materiality asserts the natural and realistic corporeality of the woman, who breaks away from the abstract image of the Petrarchan and Neo-Platonic airy lady. However, Berowne ${ }^{14}$ fails to understand and properly appreciate the deep value of Rosaline's darkness, and tries therefore to court her through canonical praise. She is called "Celestial" (IV.ii.117), "heavenly Rosaline", and is traditionally compared to a "sun that maketh all things shine" (IV.iii.244). Berowne writes sonnets to her in the highest Petrarchan style and addresses them "To the snow-white hand of the most beauteous Lady Rosaline" (IV.ii.130-131). But the sublimating Petrarchan rhetoric, the target of Shakespeare's polemic, fails to conquer the lady, who cannot recognize herself in the ideal image that the poetry conveys through standardized (in both chromatic and rhetorical terms) praise. For this reason, she is the most angry and obstinate of all, because she is the one who has been most deeply betrayed by her suitor's "whitening" rhetoric. Dark as she is, Rosaline has to read a sonnet in which she is described, or rather "painted", as "the fairest goddess on the ground. / I am compared to twenty thousand fairs. / $\mathrm{O}$, he hath drawn my picture in his letter". This picture is not faithful at all to the original. "Any thing like?", the Princess asks. "Nothing in the praise" (V.ii.36-40), answers Rosaline, but only, ironically, in the black colour of the ink: "Beauteous as ink - a good conclusion" (V.ii. 41). Rosaline feels that Berowne's love is as conventional as the language through which he expresses it, and that he is not ready to acknowledge her divergence from the ideal. It is precisely for this reason that, in a cruelly ironic moment of revenge, she decides to treat him as the traditional Petrarchan lover he seems willing to impersonate: "I would make him fawn, and beg, and seek, / And wait the season, and observe the times, / And spend his prodigal wits in bootless rhymes, / And shape his service wholly to my hests, / And make him proud to make me proud that jests! / So pursuivant-like would I o'ersway his state / That he should be my fool, and I his fate" (V.ii.62-68). ${ }^{15}$ 


\section{"A light condition in a beauty dark": A Paradoxical Beauty}

9 Even though Berowne appears not to understand the deep value of Rosaline's darkness, and does not renounce the falsifying Petrarchan rhetoric until the very end, ${ }^{16}$ the language used by both her suitor and the other characters in some sections of the play to describe Rosaline is particularly interesting. By analyzing this language closely, it is possible to notice how the chromatic terms referring to the lady give way to one of the play's most meaningful images: an extremely complex linguistic game in which the colour paradox is generated by the constant ambiguous intertwining of black and white, light and darkness. The first example of this can be found in the language used by the young detractors of the dark lady. After having linked, according to the traditional chromatic symbolism, the colour black - "thy love is black as ebony" (IV.iii. 245) - with the most negative aspects of reality - "Black is the badge of hell, / The hue of dungeons and the style of night, / And beauty's crest becomes the heavens well" (IV.iii. 252-254) -, the king and his friends appear to unconsciously produce images in which the orthodox dichotomy begins to vacillate through an oxymoronic clash of light and darkness. In particular, the paradoxical nature of a light that coincides with darkness - an image that will prove to be the heart of one of the play's deepest meanings - is expressed through highly evocative words: "O paradox! [...] Dark needs no candles now, for dark is light" (IV.iii. 252 and 267).

10 A similar oxymoronic encounter of opposite chromatic values appears in the words Berowne uses to defend his beloved from his friends' derision. Even though his celebration of the dark beauty does not truly differs from the traditional one, as it "idolizes" the black colour through a rhetoric quite similar to that proper to the Petrarchan poetry, yet the paradoxical images of light/white and darkness/black convey a meaning that goes beyond Berowne's explicit and intentional message. In lines that strongly remind us of the sonnets to the Dark Lady, Berowne proclaims that the novel beauty of the colour black is a sign of the artificial falsification of traditional beauty: "O, if in black my lady's brows be decked, / It mourns that painting and usurping hair / Should ravish doters with a false aspect, / And therefore is she born to make black fair" (IV.iii.256-259). Moreover, through an image that the king defines as a "paradox", he exalts his lady's complexion by swearing that "No face is fair that is not full so black"17 (IV.iii.256-259). The clash of terms referring to the opposite semantic fields of light/white and darkness/black increases the impression of paradoxical chromatic confusion that runs throughout the play's imagery.

11 Contextually, the princess gives voice to a similar paradox when describing her friend. While the other ladies are, in their lovers' words, "light in the light" (II.i.199), ${ }^{18}$ Katherine defines Rosaline with a very peculiar image that reverses this eulogistic monochromatic pun. Inserted in an effervescent dialogue based entirely on the oxymoronic encounter of terms referring to light and darkness - displayed in a variety of metaphorical, mostly sensual, senses ${ }^{19}$ - this image appears particularly significant. While the sexual innuendos conveyed by the idea of a "light wench" doing things "in the dark" subtly reassert the distance of Lady Rosaline from the chaste and spiritual Neo-Platonic ideal, the language through which she is described wittingly plays on the different meanings of the term "light", so that the chromatic one becomes predominant within the specific context of the phrase: "a light condition in a beauty 
dark" (V.ii.20). The paradox of "light in darkness", as opposed to the concept of "light in the light", is thus personified in Rosaline, who seems to embody a new symbolic relationship between the two opposed elements.

\section{“Light in darkness lies": A Novel Epistemology}

12 By opposing the standardized model of the Petrarchan poetry, Rosaline's darkness appears to affirm the necessity for a return to the authenticity and materiality of the body, the fleshy obscurity of which asserts itself against the white purity of the sublimated Neo-Platonic ideal. This is not, though, the only reason why Rosaline's darkness should be considered as the symbolic heart of the play. In fact, this darkness corresponds to the play's epistemological discovery: the impossibility that true knowledge can be obtained through the annihilation of man's "dark parts", body and passion. While the acknowledgment of the darkness proper to the body sanctions the rightful existence of the realm of matter and flesh, the epistemological project with which the play opens is revealed to be impossible to carry out without the direct experience of the material world's darkness. This epistemological revolution is crystallized in a splendid image that, by making use of the novel chromatic imagery employed in describing Rosaline, creates a deep bond between the novel knowledge and the new lady. Just as authentic love can only be reached through Rosaline's dark beauty, true knowledge can only be obtained by seeking the rays hidden in the darkness of matter, not by denying the body and the material world, nor by directly observing light through reason's light:

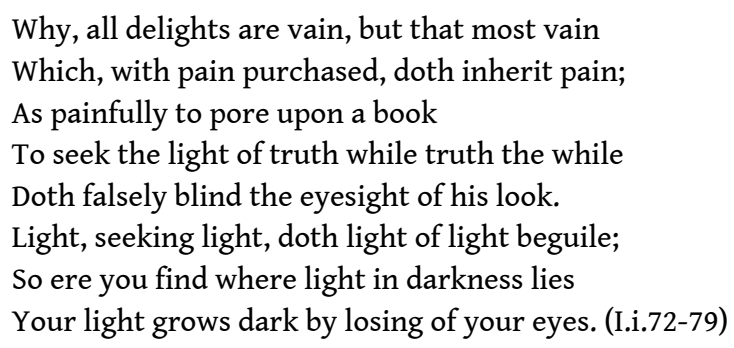

13 The shift from the kind of ascetic knowledge initially proposed by the king, to be obtained through a "still and contemplative" (I.i.14) attitude that excludes any earthly passion, to the new epistemology, is conveyed through a complex chromatic discourse that calls into question the absolute separation of light - the Neo-Platonic symbol of both the instrument and the object of true knowledge - from darkness - the visual representation of the flesh's earthly ignorance and sinfulness. This shift can be seen as embedded into a novel sensibility, rising in Europe at the end of the sixteenth century. This multifaceted current of thought, to which artists and thinkers such as Caravaggio, Galileo and Giordano Bruno contributed, claimed the necessity of a return to the natural and non-hierarchical world of matter - in ontological, epistemological and aesthetic terms - and often expressed this through a novel use of light and darkness. ${ }^{20}$ Without attempting here a study of this innovative approach to reality and its chromatic symbolism, the analysis of shakespeare's paradoxical language appears, in this sense, paradigmatic. The vertiginous linguistic game created by the vortex of intertwined images of light and darkness, sight and blindness, is one of the most powerful expressions of Shakespeare's symbolic luminism. The terms are carefully 
arranged to create an almost symmetric intersection that exemplifies the interchangeable nature of the traditionally opposed entities, giving birth to paradoxical images such as that of "light in darkness" and "dark light". This imagery, which will also appear in the words that Berowne chooses to mockingly address Rosaline - "When we greet, / With eyes' best seeing, heaven's fiery eye, / By light we lose light" (V.ii.374-376) -, covertly conveys an important meaning. True knowledge cannot be found by looking at the direct source of light, which would make men blind, but only by experiencing with our entire being, body and mind alike, the obscurity of the world, or, as Giordano Bruno would say, "sub umbra". The "light of truth" will then be discovered in the black eyes of a dark lady, the objective counterpart of this novel epistemology: "Study his bias leaves, and makes his book thine eyes, / Where all those pleasures live that art would comprehend. / If knowledge be the mark, to know thee shall suffice" (IV.ii.110-112).

14 The heart of the play thus appears to be a paradox: the paradox of light in darkness, fairness in blackness. This is expressed in a chromatic language that reflects through a game of multiple mirrors a frenetic and destabilizing alternation of black and white, both in conveying the novel epistemological path and in describing lady Rosaline. True knowledge is expressed in this paradox -"light in darkness lies" (I.i.78) - as opposed to the equally paradoxical image of the "light in light" generating blindness. Contextually, the lady through whom this knowledge can be reached is as dark as the body of the world, and endowed with a beauty that, being the physical incarnation of this paradox, is the shining of light within obscurity - "A light condition in a beauty dark" (V.ii.20) opposed to the Neo-Platonic lady who is "light in the light" (II.i.199). By using this particular imagery and endowing it with such a deep meaning, Shakespeare demonstrates his awareness not only of the prevailing ontological and aesthetic Renaissance paradigm, but also of the most controversial currents of thought of his time. These same paradoxical images of a shining darkness are hidden in the deepest and most obscure folds of Renaissance thought: not only in Bruno's heretic writings but also in the mysteries of alchemy and mystique. ${ }^{21}$ As for poetry, this same paradoxical concept will prove particularly dear to some of the contemplative poets of the seventeenth century, including Lord Herbert of Cherbury. Only a few years after Shakespeare, he will write splendid poems where the celebration of a dark beauty shining with inner light - "shining light in darkness" 22 - paves the way to a deep reflection on the mystical value of darkness, which finds in the oxymoron of the luminous blackness - "thy blackness is a spark / Of light inaccessible" 23 - its most fascinating symbol. ${ }^{24}$

\section{Conclusion}

The analysis of Shakespeare's chromatic discourse in Love's Labour's Lost reveals a deep and controversial meaning concealed under exceptionally complex and refined linguistic games. Starting from the "orthodox" opposition of light/white and darkness/ black, Shakespeare calls into question the hierarchical nature of this conflict, thus asserting a new relation between the two opposed values that amounts to their coexistence through the paradox of a darkness generating light, or a light in darkness. By making this paradox one of the play's main symbols, and by drawing a clear parallel between Rosaline's chromatic revolution and the epistemological one, Shakespeare 
challenges the traditional dichotomous worldview in both its poetic and ontological implications, thus revealing the deep modernity of his aesthetic and philosophical thought.

\section{NOTES}

1. See for instance Frances Yates, A Study of Love's Labour's Lost, Cambridge, CUP, 1936. Yates interprets the play as a veiled attack against the circle of intellectuals gathered around Sir Walter Raleigh, allegedly known as the "School of Night". She also individuates in the text references to John Florio, George Chapman and Giordano Bruno.

2. William Shakespeare, Love's Labour's Lost, Stanley Wells, Gary Taylor, John Jowett and William Montgomery, eds., The Oxford Shakespeare. The Complete Works, 2nd edition, Oxford, OUP, 2005, I.i. 9-10. All following quotations from the play will be from this edition.

3. The Protestant anthropological pessimism, inherited from St. Augustine and patristic writers, individuates in the human flesh the dark mark of the original sin. As Alistair Fox writes: "At the heart of Elizabethan Protestantism lay a deepened sense of human sinfulness [...] [which] sprang from the Calvinist conviction that human nature was inherently depraved" (Alistair Fox, The English Renaissance. Identity and Representation in Elizabethan England, Oxford, Blackwell, 1997, p. 61).

4. This definition of man, attributed to Hermes Trismegistus, is espressed by Pico della Mirandola at the beginning of his Oratio De Hominis Dignitate. Giovanni Pico della Mirandola, Oratio De Hominis Dignitate, in Giovanni Pico della Mirandola, De Hominis Dignitate, Heptaplus, De Ente et Uno, Eugenio Garin, ed., Torino, Nino Aragno Editore, 2004, p. 103.

5. (Because man is his soul, and in that consists true beauty. And the body is his prison and his sepulchre) Giovanni Betussi, Il Raverta, in Giuseppe Zonta, ed., Trattati d'amore del Cinquecento, Bari, Laterza, 1968, p. 20.

6. Marsilio Ficino, Theologiae Platonicae, de immortalitate animorum, in Marsilio Ficino, Opera Omnia, 2 vols, Torino, Bottega d'Erasmo, 1962, vol. 1, p. 151.

7. For a study of the rhetoric of colours in the play, see: Armelle Sabatier, "The Rhetoric of Colours in Love's Labour's Lost", in Delphine Lemonnier-Texier and Guillaume Winter, eds., Lectures de Love's Labour's Lost de William Shakespeare, Rennes, Presses Universitaires de Rennes, 2014, p.117-132.

8. Michel Pastoureau, Black. The History of a Color, trans. by Jody Gladding, Princeton and Oxford, Princeton University Press, 2009, p. 39.

9. As Linda Van Norden writes: "In the Renaissance, then - even the late Renaissance - black and the entire color spectrum were studied almost as variously as Bible texts had been throughout the Middle Ages, and on a similar scale of meaning. Black, white, and the hues were phenomena to be explained physically, but they spoke, as well, a language to be understood morally, or mythologically, or mystically" (Linda Van Norden, The Black Feet of the Peacock. The Color-Concept "Black" from the Greeks through the Renaissance, ed. John Pollock, Laham, New York and London, University of America Press, 1985, p. 9).

10. (tie of the universe.) Marsilio Ficino, Liber De Lumine, in Marsilio Ficino, op. cit., vol. 1, p. 1010. Ficino dedicates several works to the study and celebration of light: Quaestio de luce, Quid sit lumen, Orphica Comparatio Solis ad Deum, Liber De Sole, Liber De Lumine. 
11. Cf. Baldassarre Castiglione, Il libro del Cortegiano, in Carlo Cordié, ed., Opere di Baldassarre Castiglione, Giovanni della Casa, Benvenuto Cellini, Milano and Napoli, Ricciardi, 1960, p. 348.

12. (With its light triumphs over the darkness of the body.) Baldassarre Castiglione, op. cit., p. 346. 13. Harold Bloom is among the many critics who highlighted this connection. See Harold Bloom, Shakespeare. The Invention of the Human, London, Fourth Estate, 1999, p. 135.

14. I chose to reproduce the character's name in the spelling variant that we find in the text's first redaction (which is also the variant chosen by William Carrol for the Cambridge edition), instead of the "Biron" variant that we find in other editions, including the Oxford Complete Works. 15. A similar "treatment" is reserved to Orlando by Rosaline's almost namesake, Rosalind. The poetry through which Orlando praises Rosalind in As You Like It consists, as in the case of Berowne's poetry, of the hyperbolic Petrarchan praise, characterized once again in chromatic terms: "All the pictures fairest lined / Are but black to Rosalind" (III.ii.90-91). This praise arouses Touchstone's irony, who defines the verses as "false", in both metrical and semantic terms. Annoyed by this idealizing and conventional poetry, Rosalind decides to "cure" her lover in a way similar to the one used by Rosaline, that is, by interpreting the "cruel" lady of the sonnet tradition: "would I [...] grieve, be effeminate, changeable, longing and liking, proud, fantastical, apish, shallow, inconstant, full of tears, full of smiles; for every passion something, and for no passion truly anything [...] would now like him, now loathe him; then entertain him, then forswear him; now weep for him, then spit at him [...] And thus I cure him" (William Shakespeare, As You Like It, in The Oxford Shakespeare. The Complete Works, op. cit., III.ii.394-405).

16. "Henceforth my wooing mind shall be expressed / In russet yeas and honest kersey noes" (V.ii.412-413).

17. Confront Berowne's words - "That I may swear beauty doth beauty lack / If that she learn not of her eye to look / No face is fair that is not full so black" (IV.iii.249-251) - with sonnet 132, l. 13-14: "Then will I swear beauty herself is black, / And all they foul that thy complexion lack" William Shakespeare, Sonnets and "A Lover's Complaint", in The Oxford Shakespeare. The Complete Works, op. cit.

18. Although the term "light" acquires here a sensual double meaning, yet the word has surely been chosen by Shakespeare by virtue of its chromatic value.

19. K: “[...] a light heart lives long." R: "What's your dark meaning, mouse, of this light word?" K: "A light condition in a beauty dark." R: "We need more light to find your meaning out." K: "You'll mar the light by taking it in snuff, / Therefore I'll darkly end the argument." R: "Look what you do, you do it still i'th' dark." K: "So do not you, for you are a light wench." R: "Indeed I weight you not, and therefore light." (V.ii.18-26).

20. See the section entitled "The Darkness" in Camilla Caporicci, The Dark Lady. La rivoluzione shakespeariana nei sonetti alla Dama Bruna, Passigano s.T., Aguaplano, 2013.

21. Alchemical treatises often refer to a luminous nigredo from which light and the colour white originate. According to the alchemical doctrine, the Nigredo (Blackness) represents the first step for the transformation of reality, the state of chaos before creation. From this darkness springs first the colour white, then red, and the entire rainbow. For this reason, among the emblems of mystical alchemy is often found the chromatic oxymoron of a darkness generating light, as in the case of the Splendor Solis, where a black man is refigured as meeting a white angel (Salomon Trismosin, Splendor Solis, trans. by Joscelyn Godwin, ed. Adam McLean, Grand Rapids, Phanes Press, 1991). Similarly, the black crow is considered the origin of any divine art, while the vulture, which is the archetype of the alchemical crow, cries in the Golden Treatise: "I am the White of the Black, and the Red of the White, and the Citrine of the Red; and I speak the very truth" (Mary Anne Atwood, ed., The Golden Treatise of Hermes Trismegistus, concerning the Physical Secret of the Philosopher's Stone, trans. by Mary Anne Atwood and Francis Barret, Edmonds, The Alchemical Press, 1998, p. 10). In the version derived from the Emerald Tablet, he reveals his deepest truth, the generation of light and the colour white from blackness: "Albus nigri iam 
ipsum album, ex nigredo extrahimus" (Ioanne Augustino Pantheo, Ars et Theoria Transmutationis Metallicae, Roma, L'Arcano, 2007). On the other hand, many Renaissance mystics speak of a divine "dazzling darkness", a "Ray of that Divine Darkness" in which God himself can be glimpsed (Dionysius the Areopagite, Mystical Theology, trans. by Clarence Edwin Rolt, Montana, Kessinger Publishing Company, 1920, p. 192).

22. E. Herbert, Lord of Cherbury, "To her Hairs”, in George C. Moore Smith, ed., The Poems English and Latin of Edward Lord Herbert of Cherbury, Oxford, Clarendon Press, 1923, 1. 34.

23. E. Herbert, Lord of Cherbury, "Sonnet of Black Beauty", op. cit., 1. 12-13.

24. In his poetry we find a deep reflection on the nature of the colour black, which becomes the symbol of divine power's infinite mystery: “Thou Black, wherein all colours are compos'd, /And unto which they all at last return, / Thou colour of the Sun where it doth burn, / And shadow, where it cools, in thee is clos'd / Whatever nature can, or hath dispos'd / In any other Hue: from thee do rise / Those tempers and complexions, which disclod's, / As parts of thee, do work as mysteries, / of that hidden power; when thou dost reign / The character of fate shine in the Skies, / And tell us what the Heaven do ordain, / But when Earth's common light shines to our eys, / Thou so retir'st thy self, that thy disdain / All revelation unto Man denys". E. Herbert, Lord of Cherbury, "Another Sonnet to Black it self", op. cit.

\section{ABSTRACTS}

The aim of this paper is to show the aesthetic as well as philosophical complexity of the discourse led by Shakespeare in Love's Labour's Lost; a comedy that conveys, through a particularly sophisticated and sometimes paradoxical language, deeply "revolutionary" meanings. The process that takes place in the play consists in a double passage, the main symbol of which is the darkness of Lady Rosaline. On the one hand, Shakespeare makes Rosaline's darkness the rock on which the traditional Petrarchan lyric founders. The falsifying character of the Petrarchan rhetorical language is in fact revealed to be misleading, while the Neo-platonic ideal at the base of the sonnet tradition, chromatically characterized as luminous and white, crashes against the obscure materiality of the lady's body. On the other hand, the exceptionally complex linguistic game through which Shakespeare ambiguously intertwines light and darkness, expresses the play's ontological and epistemological discovery. The initial denial of mankind's "material parts", associated by Navarre to an "ascetic" kind of knowledge, is followed by the recognition of matter's profound value and of a new epistemological paradigm, according to which knowledge can be reached only by directly experiencing the darkness of the material world.

Cet article analyse la complexité esthétique aussi bien que philosophique du discours de Shakespeare dans Peines d'amour perdues, comédie qui véhicule un sens profondément « révolutionnaire » au moyen d'une langue particulièrement sophistiquée et parfois paradoxale. Le double passage qui caractérise la pièce s'incarne dans la brune Rosaline. D'un côté, Shakespeare fait d'elle le rocher sur lequel vient s'échouer la poésie pétrarquiste traditionnelle. La rhétorique de Pétrarque se révèle trompeuse tandis que l'idéal néo-platonicien qui fonde la tradition du sonnet, à la gamme chromatique lumineuse et blanche, se heurte à la matérialité sombre du corps féminin. De l'autre, le jeu linguistique extraordinairement complexe par lequel Shakespeare mêle lumière et obscurité relaie la découverte ontologique et épistémologique de la pièce. L'ascétisme des hommes de Navarre laisse la place à la reconnaissance de l'importance de 
la matière dans une forme de savoir qui ne peut s'acquérir que par l'expérience directe de l'obscurité du monde matériel.

INDEX

Keywords: colour, darkness, epistemology, light, Love's Labour's Lost, Petrarchism

Mots-clés: couleur, épistémologie, obscurité, Peines d'amour perdues, pétrarquisme

\section{AUTHOR}

CAMILLA CAPORICCI

Università degli Studi di Perugia 